\title{
Comparison of Critical Thinking in Students Interested and Uninterested in Learning a Second Language
}

\author{
Gholamreza Manshaee \\ Islamic Azad University, Isfahan Science and Research Branch, Isfahan, Iran \\ Tahereh Mahmoudian Dastnaee \\ Islamic Azad University, Behshahr Branch, Behshahr, Iran \\ Ali Seidi (Corresponding Author) \\ Islamic Azad University, Gilan-E-gharb Branch, Gilanegharb, Iran \\ Azam Davoodi \\ Islamic Azad University, Isfahan Science and Research Branch, Isfahan, Iran
}

\begin{abstract}
The main objective of this study is to identify the impact of critical thinking on students interested and uninterested in learning a second language. The population consists of 2875 high school students in the city of Tehran. The sample includes 385 high school students selected through simple random sampling and the study follows a causal-comparative design. The student's age ranges from 14 to 18 years old who had at least learned one language as a second language (English). The instruments used in this study were: 1. Questionnaire on the level of interest in learning a second language 2. Critical Thinking Disposition questionnaire. The data were analyzed by the SPSS software by using the comparisons of independent sample t-test and within subjects Anova. The results showed that students interested learning a second language have higher levels critical thinking than students uninterested in learning a second language, and female students have higher levels critical thinking than male students.
\end{abstract}

Index Terms — critical thinking, interest, second language learning, motivation

\section{INTRODUCTION}

Today more than ever man is facing a huge amount of human knowledge and business and this capacity of human knowledge and business is constantly increasing every day. Although this extensive knowledge and business is easily accessible through various resources, But choosing the appropriate and on time information from the mass of information has become so difficult and requires high mental and intellectual skills. There are a variety of intellectual skills and one of the most important of them is the critical thinking skills.

But what is the nature of critical thinking? Despite the consensus of experts and scientists on the importance of critical thinking and its fostering, diverse opinions have been presented critical thinking on the definition and nature of critical thinking. (Vacek, 2009; Jones, 2007). One reason is that critical thinking is a complex concept and involves complex activity and mental processes. Therefore, it is not possible to describe and measure it easily (Wilgis \& McConnell, 2008; Bataineh \& Alazzi, 2009). Another reason is that each researcher has defined it according to his/her own understanding of the needs of his/her research (Bataineh \& Alazzi, 2009). For instance, Critical Thinking Association quoting Snyder and Snyder (2008) defines critical thinking as the process of putting thought into order, conceptualizing actively and skillfully, apply, analyze, synthesize, and evaluate collected or generated information through observation, experience, reflection, reasoning, or communication as a guide for order or action. According to Halpern (2007, as cited in Stupnisky et al., 2008), Critical thinking is the use of cognitive skills that increase the likelihood of desired results it is used to describe a thinking that is target-oriented, reason-oriented and based on guidance. The aim here includes problem solving, reasoning, formulating, estimating probabilities, and decisions making. Broadly defines critical thinking as a set of cognitive skills such as identifying central issues and assumptions, evaluating an event, and inferencing result.

Despite the controversy in definitions, there are a lot of overlaps such as Insight, wisdom, speculative thought, seeking reason, identifying underlying assumptions, problem solving, decision making, creativity, perception and evaluation. Hence, education in contemporary times needs to more focus on the process and critical thinking skills rather than content over the past times (Page \& Mukherjee, 2007). 
Some experts have considered the most important reasons for having students think critically as follows: 1) To equip students with critical thinking skills makes them aware that scientific discoveries and advances cannot guide the community alone. Instead, it is the society and its people who must control and guide discoveries and scientific advancements in the best way (Gunn et al., 2008).

1) Critical thinking enables students to effectively assess and organize the information they have gathered through books, internet and university about the current theories, criteria or standards and their methods of use and understand the amount of their correctness, value and reliability through reasoning, and thus capture them (Jawarneh et al., 2008).

2) Critical thinking develops the ability of researching, problem solving, decision making, taking advantage of different perspectives, and lifelong learning in the students. The sum of these abilities makes the students able to solve national, scientific, and practical problems (Jawarneh et al., 2008; Snyder \& Snyder, 2008).

3) Critical thinking makes students not only have sufficient knowledge or information about their area of expertise, but also make decisions about the society, politics, changing global issues and ethical challenges of daily life in today's complex world, and provide precise and accurate solutions to them (Abrami et al., 2008).

Although critical thinking is a relatively new term that has been proposed in the twentieth century, however, this activity is rooted in the thought of the ancient Greek philosophers such as Socrates, Plato and Aristotle. The philosophers generally considered critical thinking as the ability to question, examine and think about the ideas and values (Wilgis \& McConnell, 2008). Since the beginning of the twentieth century, following the development of related research on teaching and learning, critical thinking was highly emphasized (Gunn et al., 2008).

Hence, the acquisition of critical thinking skills has become more than ever an undeniable necessity in the job market, dealing with the physical and spiritual questions, evaluating ideas, people, policies, institutions, and ultimately facing social problems in today's world (Hatcher \& Spencer, 2005). In this regard, Dewey (1964) believed that critical thinking depends on judgments and commitment to skepticism (Martin et al., 2008; Bataineh \& Alazzi, 2009). Bloom et al., (1956, as cited in Page \& Mukherjee, 2007) classified the cognitive domain, and believed that students should know at least three levels of critical thinking, the analysis, synthesis and evaluation and use them to enter the world of working. Piaget (1970, as cited in Gunn et al., 2008) also pointed to the growing excellency in human life and consider it as an active knowledge constructor. Similarly, in the 1980s, the emphasis was on learning and cognitive processes, resulting in the emergence of constructivist movement and has been continuing ever increasing emphasis on critical thinking since now. Research shows that, despite the importance of critical thinking as an essential tool for learning in general, students have little ability to use critical thinking skills (Martin et al., 2008).

One of the other variables studied in this research is second language. Scholars have different perspectives on the relationship between language and thought. Some consider language as the basis of thought and others view language as independent of thinking. The followers of the first view believe that linguistic system develops though with its grammar and words and these elements are essential for its developing. According to Whorf (2007), language is not simply a tool of reinventing and transforming the mental idea into audio signals rather it constructs mental concepts and people view and understand nature along the lines which have been drawn by their native language. He claims that language determines the form of thought. Therefore, multilingual people who have high proficiency for each language use different models of thinking.

The followers of the second view consider language and thought as separate of each other and hold that the relationship between the sound of a word and its meaning, except in limited cases such as the name sounds, is a relational contract. The meaning associated with a series of speech sounds is not innate, but it must be learned. So the main source of meaning is based on the experiences of the universe and the mind; Experiences that are non-linguistic in nature. As a result, it seems that thinking is always language independent with the ideas and concepts in involves. John Locke, the famous English philosopher also believes that the relationship between language and thought is so that thought is independent of language, but language is the outcome of thought. Assuming such a relationship, language has the fundamental role and is mean for the expression and exchange of thought (Modaresi, 2008).

Critics in criticizing the view of language as the basis of thought, argue that if language was the basis of thought the deaf children who do not have language would not be able to think, while these children show a logic based intelligent behavior to the environment like hearing children when playing or doing other activities. Although each of these approaches cite specific evidence and reasons to prove their claims but the most likely relationship between language and thought can be the one which assumes that the mental state of mind is specifically rooted in resources which are distinctive of language. Just when thought is formed from the child's experiences in the world of objects, events and situations language is able to be acquired. Then, over time, a complete language system is formed through thought.

Vygotsky (1978) argues that language and thought are grown separately, but language gradually becomes a powerful tool for thinking. He was speaking of a certain type of speech which he refers to as talking to self or inner speech which is different from social speech which children use when communicating with ideas. Of course the denial of language as the basis of thought does not mean that language never has a role in the content or directing an individual's thoughts. Vygotsky considers communication and social interaction as the primary functions of language, and views its role as very important in the process of child's mental development and communication with parents. In this theory, all essential human cognitive functions such as logical memory, open attention, spoken thought, speech concept formation and spoken system are in the social context and can be converted into a psychological phenomenon through enhanced 
internalization. He extends the concept of language and cognition to the cultural dimension of development and stresses on the importance of the quality of social and cultural interaction in language development, and cultural diversity and differences (Arefi, 2003).

It is clear that knowledge of language is an acquired skill not inherited and every human being can learn a language. So many people are prepared to learn a second language, especially English, because they believe that mastery in this language improves their future. While English is the most widely used language in history, it is also the language of science, technology, diplomacy, international trade and commerce. Half of Europe's trade is conducted in English and more than $66 \%$ of the world's scientists are studying through English. In addition, 80 percent of electronic stored information is in English. Even experts have concluded that a one in three person speaks English or understand it somehow.

The present decade and the past half century is different to all what is known of history. Very deep and broad changes have influenced all human activities which have not had similar instances in the past. Training courses based on the transfer of constant source of information by teachers to passive students are not suitable for the present and future anymore. Brains accumulated of inflexible materials cannot grasp the complexity and dynamics of present and future. It should not be forgotten that teachers teach a group of people and every teaching process should make the student and the teacher more emotionally richer (Shamir \& Michal, 2008).

As Klag and Bradley (2004) has noted, factors such as the attitudes and interests of students, the curriculum, the needs of society, the mindset of the teacher and his teaching methods are effective in language learning. In this regard Hatcher and Spencer (2005) carried a research on the factors affecting English language learning and interest in English. He considered good curriculum and teaching, engaging students in the teaching and learning process, creating the suitable environment for learning, sharing teachers, administrators and parents in school decisions and the functionality of the teacher's knowledge as the most important factors creating interest and motivation for achieving the assigned objectives of learning the English language.

Luk et al., (2011)'s research on brain and bilingualism showed that bilingual individuals have a stronger bordering in the cortical area both while listening to fast speech hearing slow speech. The results of studies on the relationship between bilingualism and thinking, and positive and negative consequences of bilingualism are also different and sometimes conflicting as the above views. But in fact, many researchers believe that bilingualism are connected to cognitive factors such as problem solving, creative thinking skills, divergent thinking, domain independence, and concept formation.

By studying critical thinking in students interested and uninterested in learning a second language another influential factor can be identified in the interest to learn a foreign language. The significance of this issue is embedded in the point that if the hypothesis that critical thinking is seen more in the interested students, we can engage in increasing critical thinking in the uninterested students so that we might their improvement in learning English language and therefore make an innovation in the field of English language learning. Many studies have been carried out on the factors influencing second language learning and also factors influencing the problems in learning a language.

With regard to the proposed problem two questions are presented here:

1. Does critical thinking have a significant impact on student's second language learning?

2. Is there a significant difference in male and female student's critical thinking?

\section{REVIEW OF LITERATURE}

The present study has a causal-comparative design.

\section{Participants}

The sample population and sampling method: The population in this study consists of all the high school students in the city of Tehran in the year 2012. The student's age ranges from 14 to 18 years old who had at least learned one language as a second language (English) and their number is 2785. Cochran's formula was used to estimate sample size and sample size of 385 was obtained. Simple random sampling was used as the sampling method.

\section{Instruments}

The instruments used in this study were: 1 . Questionnaire on the level of interest in learning a second language. This is a self-report scale of interested or lack of interest in learning a second language which was diagnosed by specialists in psychology and to estimate the reliability of questions, they were given to 25 students in both groups and after gathering the necessary information, it was studied through Cronbach test and it w-as known as reliable at the alpha value of 0.92 . 2. Critical Thinking Disposition questionnaire. This questionnaire which is a self-report instrument that measures the tendency of critical thinking and has 33 items and three sub-scales: creativity (11 items), development ( 9 items), and commitment (13 items). Critical Thinking Disposition Questionnaire is made based on Facione's Critical Thinking Scale (1990). Subjects have to determine the extent of their agreement or disagreement in a 5-degree Likert scale (from strongly disagree $=1$ to strongly agree $=5$ ).

To standardize the critical thinking dispositions questionnaire, Ritks gave it to 60 agriculture students studying in second year of university. Reliability coefficient of the sub-scale was as follows: Creativity subscale $=0.75$, Development subscale $=0.57$, and Commitment subscale $=0.86$ and a group of teachers confirmed the face validity of the scale. In addition, since this scale is based on the original work prepared by Facione, its validity is also confirmed. 


\section{Procedure}

The present study was conducted in two phases: the first phase, making the scale of interest in second language and standardization of critical thinking disposition scale (CTDI). Second, selection of subjects, implementation of tests and study the data: Subjects were randomly selected among high school students in Tehran. Each student responded to questions during a session lasting 55-45 minutes. At the end, after the data was collected, independent t-test was used to test the hypotheses.

\section{RESULTS}

TABLE (1):

THE STATISTICAL INDICATORS OF CRITICAL THINKING SUBSCALES BASED ON INTEREST IN STUDENTS INTERESTED AND UNINTERESTED IN LEARNING A SECOND LANGUAGE BASED ON GENDER

\begin{tabular}{|l|l|l|l|l|l|l|l|l|}
\hline \multirow{2}{*}{$\begin{array}{l}\text { Statistical indicators } \\
\text { Options }\end{array}$} & \multicolumn{2}{l|}{ Interest in second language } & \multicolumn{2}{l|}{ Lack of interest in second language } \\
\cline { 2 - 9 } & mean & male & female & male & female & male & female & male \\
\cline { 2 - 9 } & Female & 3.21 & 0.725 & 0.401 & 1.81 & 2.44 & 0.637 & 0.631 \\
\hline creativity & 3.52 & 3.58 & 0.886 & 0.489 & 1.88 & 0.788 & 2.65 & 0.771 \\
\hline development & 3.97 & 3.75 & 0.839 & 0.401 & 2.37 & 2.75 & 0.632 & 0.785 \\
\hline commitment & 4.02 & 3.51 & 0.806 & 0.430 & 2.02 & 2.62 & 0.682 & 0.672 \\
\hline Critical thinking & 3.84 &
\end{tabular}

The data presented in table (1) shows the average score of the critical thinking subscales in male and female students interested and uninterested in learning a second language

Main hypothesis: There is a significant difference in the critical thinking aspects between female and male students interested and uninterested in learning a second language.

TABLE (2):

WITHIN GROUP FACTORS

\begin{tabular}{|l|l|}
\hline Row & Within group factors \\
\hline 1 & creativity \\
\hline 2 & development \\
\hline 3 & commitment \\
\hline
\end{tabular}

The above table shows the within groups factors that include the critical thinking components (creativity, development, and commitment)

TABLE (3):

BETWEEN GROUP FACTORS

\begin{tabular}{|l|l|}
\hline Row & Between group factors \\
\hline 1 & Students interested in learning a second language \\
\hline 2 & Students uninterested in learning a second language \\
\hline 3 & female \\
\hline 4 & male \\
\hline
\end{tabular}

The above table shows the between groups in two groups (students interested and uninterested in learning a second language based on gender)

TABLE (4):

THE IMPACT OF WITHIN GROUP AND BETWEEN GROUP FACTORS

\begin{tabular}{|l|l|l|l|l|l|}
\hline Source & Sum square & df & Mean square & f & sig \\
\hline within group factors & 14.92 & 2 & 7.46 & 103.94 & 0.001 \\
\hline $\begin{array}{l}\text { Interaction of within group factors and } \\
\text { groups }\end{array}$ & 1.28 & 2 & 0.642 & 8.94 & 0.001 \\
\hline $\begin{array}{l}\text { Interaction of within group factors and } \\
\text { gender }\end{array}$ & 0.323 & 2 & 0.161 & 2.24 & 0.106 \\
\hline Interaction impact & 1.06 & 2 & 0.532 & 7.41 & 0.001 \\
\hline error & 54.84 & 764 & 0.072 & & \\
\hline
\end{tabular}

The results of the above table show that the observed $\mathrm{f}(\mathrm{f}=7.41)$ obtained from the interaction impact (within group and between group factors) when alpha is .01 and with \%99 certainty the null hypothesis is rejected.

The impact of within group's factors is not significant with regard to gender but the impact of within group's factors and groups (students interested and uninterested in learning a second language) is significant at the alpha level of .01. As a result, it can be stated that there is a significant difference in the critical thinking components of students interested and uninterested in learning a second language but these differences are not significant within groups with regard to gender. 
TABLE (5):

THE IMPACT OF BETWEEN GROUP'S FACTORS

\begin{tabular}{|l|l|l|l|l|l|}
\hline Source & Sum square & $\mathrm{df}$ & Mean square & $\mathrm{f}$ & sig \\
\hline Intercept & 3470.17 & 1 & 3470.17 & 2184.92 & 0.001 \\
\hline $\begin{array}{l}\text { students interested and uninterested in } \\
\text { learning a second language }\end{array}$ & 177.78 & 1 & 177.78 & 111.93 & 0.001 \\
\hline gender & 1.73 & 1 & 1.73 & 1.10 & 0.294 \\
\hline Interaction (groups * gender) & 20.64 & 1 & 20.64 & 12.99 & 0.001 \\
\hline error & 606.71 & 382 & 1.58 & & \\
\hline
\end{tabular}

The results of the above table show that the observed $\mathrm{f}(\mathrm{f}=12.99)$ obtained from the interaction impact of within group and between group factors (male and female students interested and uninterested in learning a second language) is significant at the alpha level of .01 and with \%99 certainty the null hypothesis is rejected. As a result, it can be said that there is a significant difference in the critical thinking of male and female students interested and uninterested in learning a second language.

\section{at sex $=$ female}

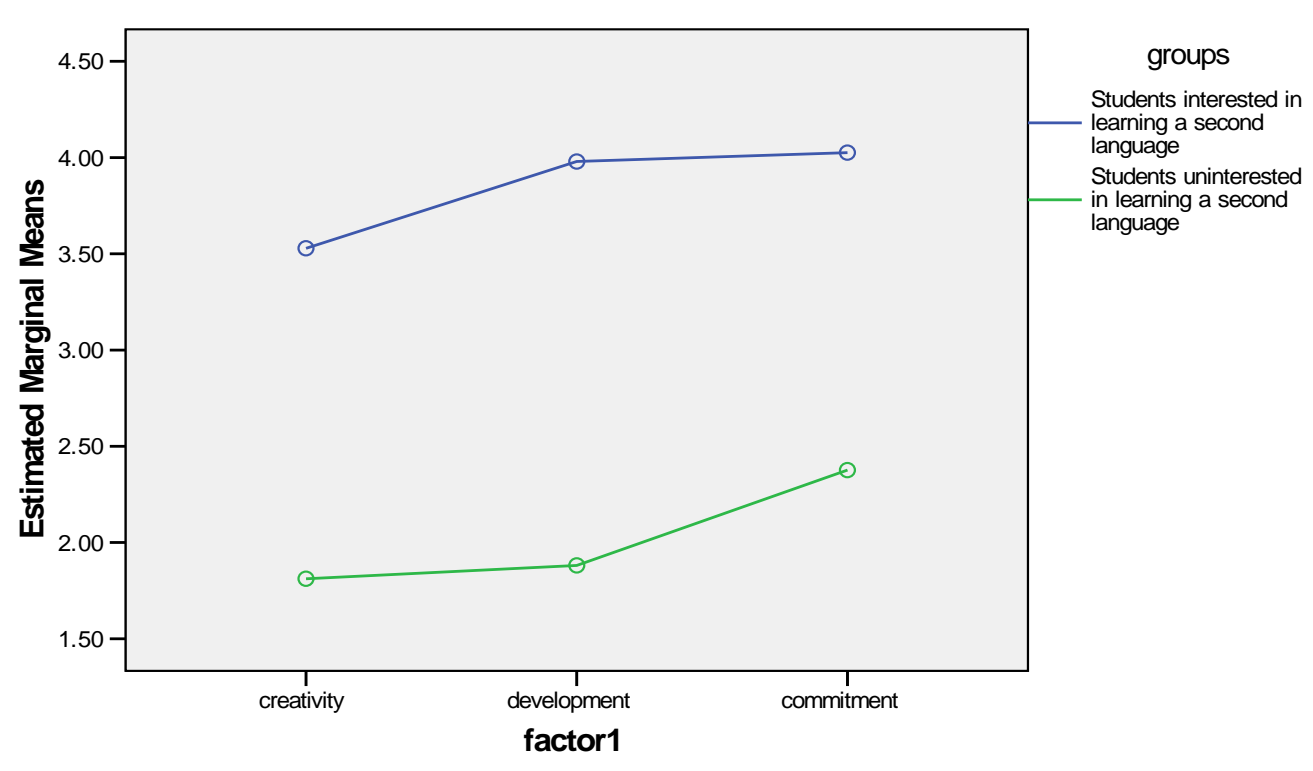

The above figure shows the average score of critical thinking aspects in female students interested and uninterested in learning a second language. As can be seen, intersected students have a higher mean in all aspects and the within group mean also shows that the interested students have a higher mean in the commitment and development aspects and uninterested students have a higher mean in commitment aspect. 


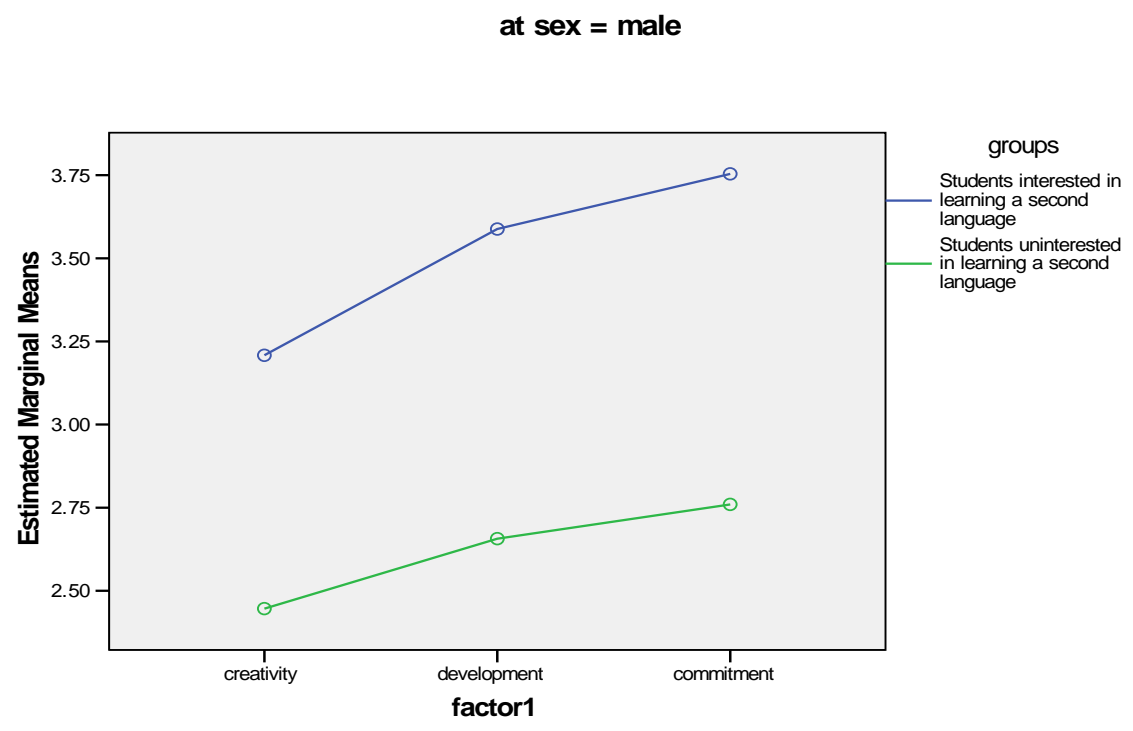

The above figure shows the average score of critical thinking aspects in male students interested and uninterested in learning a second language. As can be seen, intersected students have a higher mean in all aspects and the within group mean also shows that both groups have a higher mean in the commitment and development aspects than the creativity aspect.

First hypothesis: There is a significant difference in the critical thinking of students interested and uninterested in learning a second language.

TABLE (6)

T-TEST TO COMPARE CRITICAL THINKING OF STUDENTS INTERESTED AND UNINTERESTED IN LEARNING A SECOND LANGUAGE

\begin{tabular}{|c|c|c|c|c|c|c|}
\hline & \multirow[t]{2}{*}{ mean } & \multicolumn{2}{|c|}{ Variances Leven's Test for Equal } & \multicolumn{3}{|c|}{ t-test for Equality of Means } \\
\hline & & $\mathrm{f}$ & sig & $\mathrm{df}$ & $\mathrm{t}$ & sig \\
\hline $\begin{array}{l}\text { Interested in learning a second } \\
\text { language }\end{array}$ & 3.81 & \multirow[t]{2}{*}{2.05} & \multirow[t]{2}{*}{0.153} & \multirow[t]{2}{*}{384} & \multirow[t]{2}{*}{16.36} & \multirow[t]{2}{*}{$0.001^{*}$} \\
\hline $\begin{array}{l}\text { Uninterested in learning a } \\
\text { second language }\end{array}$ & 2.57 & & & & & \\
\hline
\end{tabular}

Results obtained from table (6) shows that the critical thinking score of students interested in learning a second language is 3.81 and the students uninterested in learning a second language is 2.57 . As can be seen, the mean of critical thinking in students interested in learning a second language is more than the mean of critical thinking in students uninterested in learning a second language. The results of $\mathrm{t}$-test showed that the observed $\mathrm{t}$ is $(\mathrm{t}=16.36)$ at the alpha level of 0.01 and the null hypothesis is rejected. In fact, results of comparing the means indicate that it can be claimed with 99 percent certainty that critical thinking is more in students interested in learning a second language than students uninterested in learning a second language.

Second hypothesis: There is a significant difference in the critical thinking of male and female students.

TABLE (7)

INDEPENDENT GROUP T-TEST TO COMPARE CRITICAL THINKING IN MALE AND FEMALE STUDENTS

\begin{tabular}{|l|l|l|l|l|l|l|}
\hline \multirow{2}{*}{} & \multirow{2}{*}{ mean } & Variances Leven's Test for Equal & \multicolumn{2}{l}{ t-test for Equality of Means } \\
\cline { 3 - 6 } & & $\mathrm{f}$ & $\mathrm{sig}$ & $\mathrm{Df}$ & $\mathrm{t}$ & $\mathrm{sig}$ \\
\hline Female students & 3.71 & 1.58 & 0.127 & 384 & 11.65 & $0.001 *$ \\
\hline Male students & 2.73 & & & & \\
\hline
\end{tabular}

Results obtained from table (7) shows that the critical thinking score of female students is 3.71 and male students is 2.73. As can be seen, the mean of critical thinking of female students is more than the mean of critical thinking of male students. The results of $t$-test showed that the observed $t$ is $(t=11.65)$ at the alpha level of 0.05 and the null hypothesis is rejected. Results of comparing the means show that it can be claimed with 95 percent certainty that critical thinking is more in female students than in male students.

\section{CONCLUSION}


The findings of this study suggest that critical thing in students uninterested in learning a second language is at a low level.

In fact, after the first analysis of the results it was known that 1) critical thinking in students interested in learning a second language is significantly more than students uninterested in learning a second language. 2) Critical Thinking is significantly more in female students than male students. Also the descriptive results of this study indicate that female students are more interested in learning a second language which can be inferred that female student's more interest in learning a second language can be due to their higher level of critical thinking. In the field of critical thinking components in male and female students, the group interested in learning a second language had a higher mean in all aspects.

The findings of this study are in line with the results of many recent researches that suggests boosting effects of bilingualism and its impact on cognitive performance such as possible accuracy control (Bialystok, 2007) and divergent thinking skills (Konaka, 1997). In contrast, the findings of this study are not in line with study of Baker (1988) who pointed to the damaging effects of bilingualism on cognitive factors.

Regarding low degrees of critical thinking in students uninterested in learning a second language, we can refer to studies of Eslami (2004) and Karimi (2010). In separate studies, they examined critical thinking skills in students and administrators and achieved fairly comparable results and showed that critical thinking skills are at a low level in their study groups. The results of Thomas (1999) study suggest that many teachers have little awareness of the concept of critical thinking and its standards which has led to the situation that they do not make the necessary effort in teaching students to develop critical thinking skill.

Paul (2000, as cited in Maleki \& Habibi, 2007) investigated 38 public universities and 28 private universities and stated that although all teachers have accepted the teaching of critical thinking as one of the primary goals of university, but few of them have a clear definition of this concept and are unaware of its constituent components. One possible reason for the low critical thinking of students may be that they are unaware of the nature of critical thinking and its learning skills and also teacher's little emphasis on active teaching methods and neglecting development of critical thinking skills in the content of the formal curriculum.

Thus, according to the obtained results, further research can be done in this area such as by teaching critical thinking to students and its development in them, we can increase their interest in learning the English language and thus provide an achievement in this area for them which is a new and valuable step forward in the field of teaching and learning. It is not unlikely that teaching critical thinking by teachers and their teaching methods in the classroom can also lead to their progress in other subjects as well.

\section{REFERENCES}

[1] Abrami, C. P., Bernard, R. M., Borokhovski, E., Wade, A., Surkes, M. A., Tamim, R., and Zhang, D. (2008). Instructional intervention affecting critical thinking skills and dispositions: A stage 1 meta-analysis. Review of Educational Research, 78(4), 1102-1134. doi: 10.3102/0034654308326084.

[2] Arefi, M. (1382). Examining the linguistic skills of bilingual children with different cultural and economic backgrounds. Journal of Educational innovation, 2(6), 57-68.

[3] Baker, C. (1988). Key issues in bilingualism and bilingual education. Philadelphia: Multilingual Matters.

[4] Batanieh, O., \& Alazzi, F. K. (2009). Perceptions of Jordanian secondary schools teachers towards critical thinking. International education, 38(2), 56-72.

[5] Bialystok, E. (2007). Cognitive effects of bilingualism: How linguistic experience leads to cognitive change. International Journal of Bilingual Education and Bilingualism, 10, 210-223.

[6] Dewey, J. (1964). Impressions of Soviet Russia and the revolutionary world, Mexico, China, Turkey, 1929. New York: Teachers College Press.

[7] Eslami, M. (1383). Providing a model for designing and implementing programs on critical reading and its evaluation on critical thinking and analytical writing. Ph.D. Dissertation, Teacher Training University, Tehran, Iran.

[8] Facione, P. A. (1990). Critical thinking: A statement of expert consensus for purposes of educational assessment and instruction. Executive Summary "The Delphi Report” Millbrae, CA, USA: California Academic Press.

[9] Gunn, T. M., Grigg, L. M., and Pomahac, G. A. (2008). Critical thinking in science education: Can bioethical issues and questioning strategies increase scientific understandings? The journal of Educational thought, 42(2), 165-183.

[10] Hatcher, D. \& Spencer, L. A. (2005). Reasoning and writing: From critical thinking to composition. Boston: American press.

[11] Jawarneh, M., Iyadat, W., Al-Shudaifat, S., and Khasawneh, L. (2008). Developing critical thinking skills of secondary student in Jordan utilizing Monro and Slater strategy and McFarland strategy. IJAES, 3(1), 82-91.

[12] Jones, A. (2007). Multiplicities or manna from heaven? Critical thinking and the disciplinary context. Australian journal of Education, 51(1), 84-103.

[13] Karimi, A. (1389). The relationship between critical thinking skills and human relations of training managers. Master's thesis, Bu-Ali Sina University, Hamadan, Iran.

[14] Klag, S., \& Bradley, G. (2004). The role of hardiness in Stress and illness: An exploration of the effect of negative affecti vity and gender. British Journal of Health Psychology, 9(2), 137-161.

[15] Konaka, K. (1997). The relationship between degree of bilingualism and gender to divergent thinking ability among native Japanese-speaking children in New York area. Doctoral dissertation, New York University, New York, U.S.

[16] Luk, G., Bialystok, E., Craik, F. I., and Grady, C. L. (2011). Lifelong bilingualism maintains white matter integrity in older adults. The Journal of Neuroscience, 31(46), 16808-16813. 
[17] Maleki, H., \& Habibipour, M. (1386). The development of critical thinking as the fundamental purpose of education. Journal of Educational Innovations, 19(6), 93-108.

[18] Martin, L., Thompson, S. D., and Richards, L. (2008). Online scenarios in FCS college courses: Enhancing critical thinking skills. Journal of Family and Consumer Sciences, 100(2), 25-30.

[19] Modaresi, Y. (2008). A review of Sociolinguistics. Tehran: Institute Humanities and Cultural Studies.

[20] Page, D., \& Mukherjee, A. (2007). Promoting critical thinking skills by using negotiation exercises. Journal of Education for Business, 82(5), 251-257. DOI:10.3200/JOEB.82.5.251-257.

[21] Shamir A., Zion, M., and Levi, O. S. (2008). Peer tutoring, metacognitive processes and multimedia problem-based learning: The effect of mediation training on critical thinking. Journal of Science Education and Technology, 17(4), 384-398.

[22] Snyder, L. G., \& Snyder, M. J. (2008). Teaching Critical thinking and problem solving skills. The Delta Pi Epsilon Journal, 1(2), 90-99.

[23] Stupnisky, R. H., Renaud, R. D., Daniels, L. M., Hyanes, T. L., and Perry, R. P. (2008). The interrelation of first-year college students' critical thinking disposition, perceived academic control, and academic achievement. Res High Educ, 49, 513-530. DOI 10.1007/s11162-008-9093-8.

[24] Thomas, F. (1999). About the California critical thinking disposition inventory. Indiana: Indiana center for postsecondary research.

[25] Vacek, J. K. (2009). Using a conceptual approach with concept mapping to promote critical thinking. Journal of Nursing Education, 48(1), 45-49.

[26] Vygotsky, L. S. (1978). The development of concept formation in adolescence. In R. van der Veer \& J. Valsiner (Eds.), The Vygotsky reader. Oxford: Blackwell Publishing.

[27] Whorf, B. L. (2007). Language, thought and reality: Selected writings of Benjamin Lee Whorf. Cambridge, MA: MIT Press.

[28] Wilgis, M., \& McConnell, J. (2008). Concept mapping: An educational strategy to improve graduate nurses critical thinking skills during a hospital orientation program. The Journal of Continuing Education in Nursing, 39(3), 119-126.

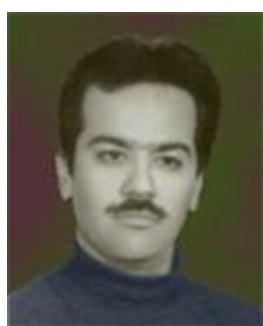

Gholamreza Monshaee has a Ph.D. in psychology. He is an assistant professor in Islamic Azad University, Naiin Branch, Naiin, Iran. Currently, he is teaching psychology courses at M.A. and Ph.D level in different national universities in Iran. He has published articles in different national and international journals and presented papers in different conferences. He has also translated some psychology books into Persian. He has had some research plans over the past years and has hold psychology workshops for the university students. $\mathrm{He}$ is also the reviewer of some national journals. His research interests are psychology, social psychology, behavior psychology, clinical psychology, and linguistic studies.

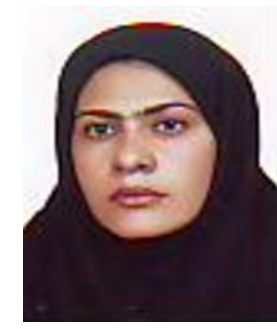

Tahereh Mahmoudian Dastnaee is a Ph.D. candidate in psychology at Islamic Azad University, Science and Research Branch, Isfahan, Iran. She is faculty member in Islamic Azad University, Behshahr Branch, Behshahr, Iran. She has been teaching psychology courses in university for more than 6 years. She has published articles in national journals. Her research interests are clinical psychology, social psychology, behavior psychology, statistical studies, and psycholinguistics.

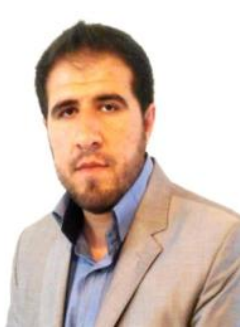

Ali Seidi is a Ph.D. candidate in TEFL at Islamic Azad University, Science and Research Branch, Tehran, Iran. He obtained his MA in Teaching English as Foreign Language (TEFL) from Iran University of Science and Technology in 2011. He is a faculty member and head of English department in Islamic Azad University, Gilan-E-Gharb Branch, Iran. He is also a university instructor at Iran University of Science and Technology and Payam nour and Islamic Azad University of Gilangharb, Kermanshah. He has published article in different academic journals. His research interests are psychological studies, CDA, Sociocultural studies, identity, and material development.

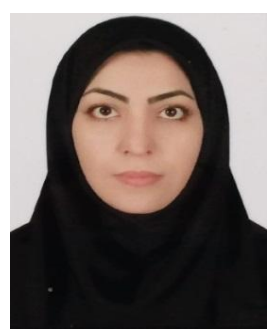

Azam Davoodi is a Ph.D. candidate in psychology at Islamic Azad University, Science and Research Branch, Isfahan, Iran. Her research interests are psychological studies, social and clinical psychology, and linguistics. 